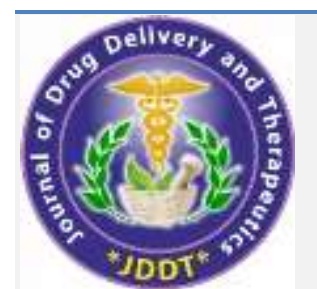

$3 \mathrm{DDT}^{4}$

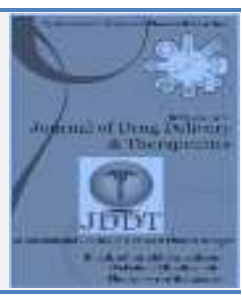

\title{
Formulation of Anti Acne Sheet Mask from Bandotan Leaf Extract (Ageratum conyzoides L.) against Propionibacterium acnes
}

\author{
Pricella Ginting1, Leny ${ }^{2 *}$, Ihsanul Hafiz ${ }^{3}$, Romauli Hasibuan ${ }^{4}$ \\ ${ }^{1}$ Department of Pharmacology and Clinical Pharmacy, School of Pharmacy, Institut Teknologi Bandung, Indonesia \\ $2^{*}$ Faculty of Pharmacy and Health, Institut Kesehatan Helvetia, Medan, Indonesia \\ ${ }^{3}$ Faculty of Pharmacy and Health, Institut Kesehatan Helvetia, Medan, Indonesia \\ ${ }^{4}$ Faculty of Pharmacy and Health, Institut Kesehatan Helvetia, Medan, Indonesia
}

Article Info:

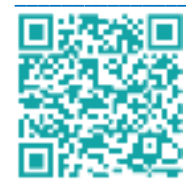

\section{Article History:}

Received 19 October 2021

Reviewed 05 December 2021

Accepted 11 December 2021

Published 15 December 2021

\section{Cite this article as:}

Ginting P, Leny, Hafiz I, Hasibuan R, Formulation of Anti Acne Sheet Mask from Bandotan Leaf Extract (Ageratum conyzoides L.) against

Propionibacterium acnes, Journal of Drug Delivery and Therapeutics. 2021; 11(6-S):123-127

DOI: http://dx.doi.org/10.22270/jddt.v11i6-S.5240

\footnotetext{
*Address for Correspondence:

Leny, Faculty of Pharmacy and Health, Institut Kesehatan Helvetia, Medan, Indonesia
}

\section{Abstract}

\begin{abstract}
Acne can occur due to increased sebum excretion, inflammation of the skin triggered by the bacteria Propionibacterium acnes, Staphylococcus epidermidis, Staphylococcus aureus. The purpose of this study was to determine the formulation of sheet mask preparations of bandotan leaf extract (Ageratum conyzoides L.) in inhibiting the growth of Propionibacterium acnes bacteria. This type of research is an experimental study which include plant identification, making ethanol extract of bandotan leaves, making sheet mask formulations, evaluating the characteristics of the preparation and testing antibacterial activity using disc paper method using Mueller Hinton Agar media. The extract was carried out by maceration using $70 \%$ ethanol as a solvent. Testing the effectiveness of antibacterial by measuring the diameter of the inhibition zone, after that the data were analyzed using the One Way ANOVA statistical test. The results of the evaluation of the preparation showed that the preparation was homogenous, with $\mathrm{pH}$ ranging from 4.5 to 6.5 and the preparation did not cause irritation on volunteers skin. The results of the inhibition zone measurements showed that the inhibition zones at $2.5 \%$ concentration is $4.7 \mathrm{~mm}, 5 \%(6.83 \mathrm{~mm}), 7.5 \%(10.2 \mathrm{~mm})$ and positive control $(20.57 \mathrm{~mm})$. This means that the higher the concentration, the larger the diameter of the inhibition zone obtained. The conclusion in this study is bandotan leaf extract (Ageratum conyzoides L.) can be formulated into anti acne sheet mask which is stable during storage with a strong inhibitory power at $7.5 \%$ concentration, which is $10.2 \mathrm{~mm}$.
\end{abstract}

Keywords: Ageratum conyzoides L., bandotan leaf, Propionibacterium acnes, sheet mask

\section{INTRODUCTION}

The skin is a protective layer that covers the surface of the body which is very vulnerable to external influences, both physical and chemical influences ${ }^{1}$. Acne can occur due to increased sebum excretion, follicle keratinization and inflammation of the skin triggered by the bacteria Propionibacterium acnes, Staphylococcus epidermidis, Staphylococcus aureus. Propionibacterium acnes is a major target in antibacterial treatment for acne because it produces several inflammatory substances that induce the development of acne lesions ${ }^{2}$.

Bandotan leaf (Ageratum conyzoides L.) is a plant that is easily available in Indonesia and is used as an alternative treatment for skin infections. Bandotan leaves contain secondary metabolites such as alkaloids, phenols, saponins, steroids/triterpenoids that can inhibit the growth of bacteria. Sheet masks are practical masks compared to other masks in the skin ${ }^{3}$.

Based on the related benefits, researchers are interested in formulating sheet mask preparations from bandotan leaf extract (Ageratum conyzoides L.) against Propionibacterium acnes bacteria.

\section{MATERIALS AND METHODS}

\section{Plants, Tools and Chemicals}

Bandotan leaf of $3 \mathrm{~kg}$ samples (Ageratum conyzoides L.) were obtained from Aektang Village, Garoga Sub-district, Kab. North Tapanuli, North Sumatra.

The tools used in this study were mortar and stamper, erlenmeyer (Pyrex), beaker glass (Pyrex), analytical balance, measuring cup (Pyrex), laminar air flow cabinet, Bunsen lamp, petri dish, blender, oven, stirring rod, filter paper, funnel, caliper, $\mathrm{pH}$ meter, object glass, autoclave, rotary evaporator, water bath, test tube, porcelain cup and incubator.

Materials used in this study were Propionibacterium acnes test bacteria, MHA (Mueller Hinton Agar), acid $\mathrm{pH}$ buffer solution (4.01), neutral pH buffer solution (7.01), $0.9 \% \mathrm{NaCl}$, $\mathrm{H}_{2} \mathrm{SO}_{4} \quad 0,36 \mathrm{~N}, \mathrm{BaCl}_{2} \mathrm{H}_{2} \mathrm{O} 1.175 \%$, xanthan gum, butylene glycol, glycerin, methyl paraben, PEG-40 Hydrogenated 
castor oil, 70\% ethanol, parfume, aquadest, sheet mask and foil bag.

\section{Simplicia Making}

The fresh leaves of Bandotan tree were collected and washed with running water, drained and weighed; the yield was $3 \mathrm{~kg}$, chopped to facilitate drying and then dried by aerating protected from sunlight. The dried simplicia was sorted to separate impurities left on the simplicia, then weighed dry, then the simplicia is mashed using a blender so that it becomes simplicia powder 4 .

\section{Plant Extraction}

Bandotan leaf simplicia powder was put into a glass container and then immersed in 75 parts of $70 \%$ ethanol solvent as much as $3750 \mathrm{ml}$ then the container was covered with aluminum foil and left for 5 days while stirring occasionally and then filtered with filter paper. The residue was then soaked again with 25 parts of $70 \%$ ethanol as much as $1250 \mathrm{ml}$ then the container was covered with aluminum foil and left for 2 days while stirring occasionally, after 2 days the sample was filtered. Filtrate one and filtrate two were mixed together and then evaporated using a rotary evaporator at $40^{\circ} \mathrm{C}$ until a crude extract was obtained 5 .

\section{Essence Formula for Sheet Mask}

Table 1: Essence formulation for sheet mask preparation

\begin{tabular}{lllll}
\hline \multicolumn{5}{c}{ Concentration (\%) } \\
\hline Ingredients & F0 & F1 & F2 & F3 \\
\hline Bandotan leaf extract & - & 2,5 & 5 & 7,5 \\
PEG-40 Hydrogenated castor oil & 0,2 & 0,2 & 0,2 & 0,2 \\
Butylene glycol & 5 & 5 & 5 & 5 \\
Glycerin & 5 & 5 & 5 & 5 \\
Xanthan gum & 0,2 & 0,2 & 0,2 & 0,2 \\
Methyl paraben & 0,3 & 0,3 & 0,3 & 0,3 \\
Ethanol & 3 & 3 & 3 & 3 \\
Perfume & Qs & Qs & Qs & Qs \\
Aquadest ad & 100 & 100 & 100 & 100
\end{tabular}

\section{Procedure of Making Sheet Mask}

Xanthan gum was put into a mortar and then dissolve it little by little with aquadest. Then added butylene glycol, glycerin, PEG-40 Hydrogenated castor oil. Added methyl paraben which has been dissolved before in hot water, grind homogenously, then added bandotan leaf extract, ethanol and perfume, grind until homogeneous ${ }^{6}$. Essence is made in 4 formulations and each essence contains $0 \%$ (F0), 2.5\% (F1), $5 \%$ (F2) and 7.5\% (F3) extract of bandotan leaf (Ageratun conyzoides L.). And the market preparation of sheet mask wardah (F4) as a positive control.

\section{Sterilization of Tools and Materials}

All tools and materials used for microbiological testing are sterilized first. The growth medium was sterilized in an autoclave at $121^{\circ} \mathrm{C}$ for 15 minutes, glass utensils were sterilized in an oven at a temperature of $160-170^{\circ} \mathrm{C}$ for $1-2$ hours, then ose needles and tweezers were sterilized by incandescent with a Bunsen flame ${ }^{7}$.

\section{Media Creation}

For this part of the study, Muller Hinton Agar (MHA) served as the medium, which was prepared by dissolving $3.8 \mathrm{~g}$ of MHA powder in $100 \mathrm{ml}$ of aquadest, after which the solution was heated and stirred until homogeneous and of clear color. Next, it was sterilized in an autoclave at $121^{\circ} \mathrm{C}$ for 15 minutes at a pressure of $1 \mathrm{~atm}$. Finally, $20 \mathrm{ml}$ of the medium was poured into each sterile Petri dish and left it solidify ${ }^{7}$

\section{Bacterial Inoculation on Oblique Agar Media}

Bacteria derived from primary culture were cultured into MHA media in a Petri dish, by taking one ose, after which they were etched into the agar medium, and were subsequently incubated for 24 hours at $37^{\circ} \mathrm{C}^{7}$.

\section{Preparation of Standard Turbidity Solution (Solution Mc. Farland)}

$9.5 \mathrm{ml}$ of $0.36 \mathrm{~N} \mathrm{H}_{2} \mathrm{SO}_{4}$ solution was mixed with $1.175 \%$ $\mathrm{BaCl}_{2.2} \mathrm{H}_{2} \mathrm{O}$ solution of $0.5 \mathrm{ml}$ in an erlenmeyer. Then shaken until a cloudy solution is formed. This turbidity can be used as a standard for the turbidity of the test bacteria suspension? ${ }^{7}$.

\section{Preparation of Test Bacterial Suspension}

Propionibacterium acnes bacteria that have been inoculated are taken with a sterile ose needle and then suspended into a tube containing $10 \mathrm{ml}$ of $0.9 \% \mathrm{NaCl}$ solution until the turbidity is the same as the turbidity standard of Mc.Farland's solution?.

\section{Evaluation of Preparation Characteristics}

\section{Organoleptic test}

Organoleptic test was carried out by observing the physical form, odor and color of the preparation ${ }^{8}$.

\section{2. pH test}

Determination of the $\mathrm{pH}$ of the preparation is done using a $\mathrm{pH}$ meter. The instrument was first calibrated using a standard neutral $\mathrm{pH}$ buffer solution ( $\mathrm{pH} 7.01)$ and an acid buffer solution $(\mathrm{pH}$ 4.01) until the instrument showed the $\mathrm{pH}$ value. Then the electrodes were washed with distilled water, then dried with a tissue. Samples were made with a concentration of $1 \%$, namely weighing $1 \mathrm{~g}$ of the preparation 
and dissolved in distilled water up to $100 \mathrm{ml}$. Then the electrode is immersed in the solution ${ }^{8}$.

\section{Homogeneity test}

A certain amount of the preparation is smeared on two pieces of glass or other suitable transparent material, the preparation must show a homogeneous arrangement and no coarse grain is seen ${ }^{7}$.

\section{Cycling test}

Stability test using the cycling test method was carried out by storing the preparation at a temperature of $\pm 4^{\circ} \mathrm{C}$ for 24 hours, then transferred to a temperature of $\pm 40^{\circ} \mathrm{C}$ for 24 hours $(1 \text { cycle })^{7}$.

\section{Irritation test}

Place the sheet mask that has been cut $\pm 2.5 \mathrm{~cm}$ behind the ear. Symptoms of irritation observed are redness, itching and swelling 8 .

\section{Antibacterial Activity Test}

Antibacterial activity was determined using paper disc diffusion method. A total of $1 \mathrm{~mL}$ of bacteria with a concentration of as much as $2.5 \%, 5 \%, 7.5 \%$ cawan poured into a petri dish containing MHA media at $40^{\circ} \mathrm{C}$. After compacting the paper, the disc containing the extract according to the concentration is placed and then incubated for 24 hours at $37^{\circ} \mathrm{C}$. The antibacterial activity is identified by the appearance of an inhibition zone, namely clear zone around the disc, thereby inhibiting bacterial growth can be determined from the width of the inhibition zone around the paper disc. The experimental design used in this study is completely randomized design with four extract treatments concentration and three replications. If analysis variance indicates that the treatment has significant effect different effects, then the real difference is determined ${ }^{9}$. This test was carried out 3 times with 9 repetitions. The data obtained were then analyzed using the One Way Anova statistical method $^{9}$.

\section{RESULT AND DISCUSSION}

\section{Organoleptic Test Results}

Table 2: The results of the organoleptic stability test of essence sheet mask preparations of bandotan leaf extract (Ageratum conyzoides L.)

\begin{tabular}{|c|c|c|c|c|c|c|c|c|}
\hline \multirow[t]{2}{*}{ Formula } & & \multicolumn{7}{|c|}{ Cycle } \\
\hline & & 0 & 1 & 2 & 3 & 4 & 5 & 6 \\
\hline \multirow[t]{3}{*}{ F0 } & Form & Thick & Thick & Thick & Thick & Thick & Thick & Thick \\
\hline & Odor & tea tree & tea tree & tea tree & tea tree & tea tree & tea tree & tea tree \\
\hline & Color & Clear & Clear & Clear & Clear & Clear & Clear & Clear \\
\hline \multirow[t]{3}{*}{ F1 } & Form & Thick & Thick & Thick & Thick & Thick & Thick & Thick \\
\hline & Odor & tea tree & tea tree & tea & tea tree & tea tree & tea tree & tea tree \\
\hline & Color & Green & Green & Green & Green & Green & Green & Green \\
\hline \multirow[t]{4}{*}{ F2 } & Form & Thick & Thick & Thick & Thick & Thick & Thick & Thick \\
\hline & Odor & tea tree & tea tree & tea tree & tea tree & tea tree & tea tree & tea tree \\
\hline & Color & Dark & Dark & Dark & Dark & Dark & Dark & Dark \\
\hline & & green & green & green & Green & green & green & green \\
\hline \multirow[t]{4}{*}{ F3 } & Form & Thick & Thick & Thick & Thick & Thick & Thick & Thick \\
\hline & Odor & tea tree & tea tree & tea tree & tea tree & tea tree & tea tree & tea tree \\
\hline & Color & Dark & Dark & Dark & Dark & Dark & Dark & Dark \\
\hline & & green & green & green & Green & green & green & green \\
\hline
\end{tabular}

The results of the organoleptic examination of the sheet mask preparation of bandotan leaf extract, namely in formula 0 in the form of a thick liquid, smells tea tree and clear in color. In formula 1, it is in the form of a thick liquid, smells of tea tree and is dark green in color. Both formula 2 $\& 3$, it is in the form of a thicker liquid, smells like tea tree and is dark green in color. The different colors occur due to the addition of the concentration of bandotan leaf extract ${ }^{7}$.

\section{Homogeneity Test Observation Results}

Based on the experiments that have been carried out on the essence of the blank sheet mask preparation (F0), no coarse grains were obtained when observed on a glass object. The same experiment was carried out on formula 1 , formula 2 , formula 3 essence for sheet mask preparation of bandotan leaf extract (Ageratum conyzoides L.) and the results obtained were the same, namely there were no coarse grains on the glass object, then the essence of sheet mask preparation of bandotan leaf extract (Ageratum conyzoides L.) can be said to be homogeneous ${ }^{9}$. 


\section{Result of Observation of pH Stability Test}

Table 3: The average results of observations of $\mathrm{pH}$ stability tests for sheet mask preparations of bandotan leaf extract (Ageratum conyzoides L.).

\begin{tabular}{ccccc}
\hline Cycle & F0 & F1 & F2 & F3 \\
\hline 0 & $6,2 \pm 0,12$ & $5,4 \pm 0,05$ & $5,26 \pm 0,03$ & $4,8 \pm 0,05$ \\
1 & $6,1 \pm 0,05$ & $5,26 \pm 0,06^{*}$ & $5,2 \pm 0,05^{*}$ & $4,8 \pm 0,05^{*}$ \\
2 & $6,1 \pm 0,05$ & $5,3 \pm 0,05^{*}$ & $5,16 \pm 0,03^{*}$ & $4,8 \pm 0,05^{*}$ \\
3 & $6,1 \pm 0,05$ & $5,26 \pm 0,03^{*}$ & $5,26 \pm 0,03^{*}$ & $4,8 \pm 0,05^{*}$ \\
4 & $6,1 \pm 0,05$ & $5,23 \pm 0,03^{*}$ & $5,23 \pm 0,03^{*}$ & $4,8 \pm 0,05^{*}$ \\
5 & $6,0 \pm 0,03$ & $5,16 \pm 0,03^{*}$ & $5,16 \pm 0,03^{*}$ & $4,8 \pm 0,00^{*}$ \\
6 & $6,0 \pm 0,03$ & $5,16 \pm 0,03^{*}$ & $5,16 \pm 0,03^{*}$ & $4,8 \pm 0,00^{*}$ \\
\hline
\end{tabular}

Description: *(significantly different from the negative control)

The $\mathrm{pH}$ test aims to determine the safety of the essence of sheet mask preparation of bandotan leaf extract (Ageratum conyzoides L.) to be used on the skin ${ }^{8}$. If the essence of the sheet mask preparation of bandotan leaf extract (Ageratum conyzoides L.) is too acidic from the $\mathrm{pH}$ of the skin, it will irritate the skin, and if it is too alkaline then the skin will be dehidrated. The higher the content of bandotan leaf extract in the essence of the sheet mask preparation, the lower the $\mathrm{pH}$ value of the preparation, it is because bandotan leaf extract contains acidic compounds. The values of the four formulas of essence sheet mask preparations meet the requirements because they are in the $\mathrm{pH}$ range between 4.7 5.6 so that they are comfortable to use topically without causing irritation or dry skin. The $\mathrm{pH}$ value of the four essence formulas for sheet mask preparations meets the skin $\mathrm{pH}$ criteria, which is between 4.5-6.5, the $\mathrm{pH}$ of the essence of sheet mask preparations is declared stable during storage ${ }^{10}$.

\section{Skin Irritation Test against Volunteers}

The irritation test of a preparation is a very important test of the quality of the preparation after application. Place the sheet mask that has been cut $\pm 2.5 \mathrm{~cm}$ behind the ear and then leave it for 24 hours. Irritation test is carried out to determine the occurrence of side effects on the skin. The test was carried out on 12 panelists which divided into 4 group of test with 3 people for one sheet mask formulation and the results showed no allergic reactions in the form of swelling, itching and redness of the skin ${ }^{11}$.

\section{Bacteria Test Results}

Table 4: Results of measuring the diameter of the inhibition zone of the sheet mask preparation of bandotan leaf extract (Ageratum conyzoides L.)

\begin{tabular}{lllll}
\hline \multirow{2}{*}{ Formula } & \multicolumn{2}{l}{ Inhibition diameter on Propionibacterium acnes (mm) } & Average inhibition (mm) \\
\cline { 2 - 5 } & 1 & 2 & 3 & 0 \\
\hline F0 & 0 & 0 & 0 & $4,7 \pm 0,264^{*}$ \\
F1 & 4,2 & 4,8 & 5,1 & $6,83 \pm 0,497^{*}$ \\
F2 & 7,6 & 5,9 & 7,0 & $10,2 \pm 0,351^{*}$ \\
F3 & 10,6 & 9,5 & 10,5 & $0,57 \pm 0,360^{*}$ \\
Positive control & 20,4 & 20,6 & 20,7 &
\end{tabular}

Description: *(significantly different from the negative control)

Inhibiting the growth of Propionibacterium acnes bacteria using the agar diffusion method, namely disc paper. The basis of this research method is that it is simple in its operation, besides that the essence of the sheet mask preparation can be absorbed into the paper $\operatorname{disc}^{7}$. The sheet mask preparation of bandotan leaf extract (Ageratum conyzoides L.) with a concentration of $2.5 \%, 5 \%$, and $7.5 \%$ respectively each has a zone of inhibition against the bacteria Propionibacterium acnes. The average diameter of the clear zone formed around the paper disc at each concentration were: $2.5 \%(4.7 \mathrm{~mm}), 5 \%(6.83 \mathrm{~mm})$, and $7.5 \%(10.2 \mathrm{~mm})$. The smallest inhibition zone was produced in sheet mask preparations of bandotan leaf extract (Ageratum conyzoides L.) with a concentration of $2.5 \%$ then the inhibition increased at concentrations of 5\% and 7.5\%. Positive control ( + ) of the Wardah sheet mask preparation had an inhibition zone of $20.57 \mathrm{~mm}$ and negative control (-) without any inhibition zone $(0 \mathrm{~mm})$.

In Table 4 it can be seen that the diameter of the largest inhibition zone and the closest to the diameter of the inhibition zone formed by the positive control was owned by a concentration of $7.5 \%$ of $10.2 \mathrm{~mm}$. While the negative control did not provide a clear zone or had no antibacterial activity at all, meaning that the clear zone that was seen was purely from the antibacterial activity of bandotan leaf extract. This proves that the higher the concentration of the sheet mask preparation of bandotan leaf extract (Ageratum 
conyzoides L.) the better it is to inhibit bacterial growth. One of the factors that affect the activity of antimicrobial substances, namely the concentration of antimicrobial substances. The inhibitory power produced by antimicrobial materials will be higher if the concentration is also high. The inhibition of bacterial growth or bacterial death due to an antibacterial substance can be caused by inhibition of cell wall synthesis, inhibition of cell membrane function, inhibition of protein synthesis, or inhibition of nucleic acid synthesis ${ }^{12}$.

According to WHO, the technical factors that affect the size of the inhibitory power of the disc diffusion method include: inoculum density, disc insertion time, incubation temperature, plate size, agar media thickness, and antimicrobial disc spacing, antimicrobial disc potential, media composition ${ }^{13}$.

\section{CONCLUSSION}

Bandotan leaf extract (Ageratum conyzoides L.) can be formulated in sheet mask dosage form which is stable during storage. The sheet mask formulation of bandotan leaf extract (Ageratum conyzoides L.) with a concentration of $2.5 \%$ with an inhibition zone of $4.7 \mathrm{~mm}$ was less effective at inhibiting the growth of Propionibacterium acnes bacteria. Formula F2 with $5 \%$ extract concentration had an inhibition zone of 6.83 $\mathrm{mm}$. Formula F3 with extract concentration of $7.5 \%$ is the best, because it can inhibit the growth of Propionibacterium acnes bacteria by $10.2 \mathrm{~mm}$. The higher the concentration of addition of bandotan leaf extract (Ageratum conyzoides L.) the more effective it is to inhibit the growth of Propionibacterium acnes bacteria. All preparations are homogeneous, fulfil $\mathrm{pH}$ requirement in a range of 4.7-5.6, do not irritate the skin, and stable during storage.

\section{CONFLICT OF INTEREST}

All authors have nothing to declare.

\section{REFERENCES}

1. Swarnali R, Sankhdip B, Dharubjyoti S, Sanjit M, Sipra S, Sudip S, Kumar M, "Formulation And Evaluation Of Anti-Acne Gel Containing Murraya Koeinigii Extract" Internatonal journal of current phamaceutical research, 2020; 108-110. https://doi.org/10.22159/ijcpr.2020v12i4.39095

2. Supomo, Anita A, Titin P, Ainur R, "Formulation of Antiacne Cream Dosage Form Containing Mangosteen (Garcinia mangostana L.) Pericarp Ethanolic Extract" Akademi Farmasi Samarinda, 2018; 37-39 https://doi.org/10.32734/idjpcr.v1i1.207
3. Selvira AIM, Doni AN, Shendi S, Sumia A, "Antibacterial Activity of Bandotan (Ageratum conyzoides L.) Leaves extracts Against Methicillin-Resistant Staphylococcus aureus" Borneo journal of pharmacy, 2020; 243-245 https://doi.org/10.33084/bjop.v3i4.1552

4. Prasetyorini D, Novi FU, Noerma V, Anggita R, Afrizal NI, " Antibacterial Activity Tests of Staphylococcus aureus and Phytochemical Screening in Family, Clusiaceae, Phyllanthaceae", Systematic Review Pharmacy, 2020; 323-325.

5. Fitri K, Khairani T, Sianturi KT, Leny L, Hafiz I, "Anti-inflammatory Activity of Ethanol Extract of Lotus (Nelumbo nucifera G.) Seed Against White Male Rats Using Paw Edema Method" Journal of Drug Delivery and Therapeutics, 2021; 11(4):1-4. https://doi.org/10.22270/jddt.v11i4.4918

6. Leny, Fitri K, Marantina R, et al., "The Moisturizing Sheet Mask Formulation of Black Soybean (Glycine soja) Ethanolik Extract" International Jurnalof Advanced Science and Technology, 2020; 29(4):9045-9051.

7. Gislene GFN, Juliana L, Paulo CF, Giuliana LS, "Antibacterial Activity Of Plant Extracts And Phytochemicals On AntibioticResistant Bacteria", Brazilian Journal of Microbiology, 2000; 247- 249.

8. Anggun HK, "Formulation and physical evaluation sheet mask from red rice (Oryza nivara) and virgin coconut oil (Cocos nucifera L)" Pharmacy Study Program Universitas Buana, 2020; 61-62.

9. Leny, Ginting EE, Hafiz I, "Formulation and Evaluation of Candlenut (Aleurites moluccana L.) Oil in Gel Preparation" Asian Journal of Pharmaceutical Research and Development, 2020; 8(5):41-43.

10. Leny, Karsono, Harahap U, "Comparison of Vitamin C (Magnesium Ascorbyl Phosphate) Formulation in Nanoemulsion Spray and Cream as Anti-aging" International Journal of PharmTech Research, 2016; 9(9):399-407.

11. Leny, Hanum SF, Wati SNE, Sundari L, "Formulasi dan uji aktivitas antibakteri sediaan spray mikroemulsi ekstrak daun pepaya (Carica papaya L.) terhadap Staphylococcus epidermidis", Health Sciences and Pharmacy Journal, 2020; $4(2): 60-65$.

12. Tristia R, Zulfitri, Desi MA, "Antibacterial Activity of Red Betel (piper crocatum) Leaf Methanolic Extracts Aginst Methicilin Resistant Staphylococcus aureus", Microbiolgy Departemen faculty of Medicine, 2012; 270- 272.

13. Muctaromah B, Ahmad M, Romaidi, Nazilah LA, Naja NA, "Antibacterial activity of water and ethanol extract of Allium sativum, Curcuma mangga, and Acorus calamus combination" Journal of Biological Researches, 2018; 24(1):8-17. https://doi.org/10.23869/bphjbr.24.1.20182 